\title{
Effect of the Atlantic Multidecadal Variability on the global monsoon
}

Article

Accepted Version

Monerie, P.-A., Robson, J., Dong, B., Hodson, D. L. R. and Klingaman, N. P. (2019) Effect of the Atlantic Multidecadal Variability on the global monsoon. Geophysical Research Letters, 46 (3). pp. 1765-1775. ISSN 0094-8276 doi: https://doi.org/10.1029/2018GL080903 Available at https://centaur.reading.ac.uk/82038/

It is advisable to refer to the publisher's version if you intend to cite from the work. See Guidance on citing.

To link to this article DOI: http://dx.doi.org/10.1029/2018GL080903

Publisher: American Geophysical Union

All outputs in CentAUR are protected by Intellectual Property Rights law, including copyright law. Copyright and IPR is retained by the creators or other copyright holders. Terms and conditions for use of this material are defined in the End User Agreement.

\section{www.reading.ac.uk/centaur}

\section{CentAUR}

Central Archive at the University of Reading 
Reading's research outputs online 


\title{
Effect of the Atlantic Multidecadal Variability on the global monsoon
}

(1)

\author{
Paul-Arthur Monerie, Jon Robson, Buwen Dong, Dan Hodson and Nick Klingaman \\ National Centre for Atmospheric Science, Department of Meteorology, University of Reading \\ Corresponding email address: p.monerie@ reading.ac.uk
}

\begin{abstract}
We assess the effect of the Atlantic Multidecadal Variability (AMV) on the global monsoon using idealized simulations. Warm AMV phases are associated with a significant strengthening of monsoon precipitation over Northern Africa and India, and anomalously weak monsoon precipitation over South America. Changes in monsoon precipitation are mediated by a change in atmospheric dynamics, primarily associated with a shift in the circulation related to both an enhanced interhemispheric thermal contrast and the remote impact of AMV on the Pacific Ocean, through changes in the Walker circulation. In contrast, the thermodynamic changes are less important. Further experiments show that the impact of AMV is largely due to the tropical component of the sea surface temperature anomalies. However, the extratropical Atlantic also plays a role, especially for northern Africa. Finally, we show that the effect of AMV on monsoons is not linearly related to the magnitude of warming.
\end{abstract}

Key points:

- Changes in atmospheric circulation dominate the AMV effect on monsoons, whilst thermodynamic changes are moderate.

- The tropical North Atlantic largely forces AMV effects, by strengthening inter-hemispheric thermal gradients and the Walker circulation.

- The effects of AMV are not linearly related to the magnitude of warming. 
The North Atlantic Sea Surface Temperature (NASST) has undergone strong variations on decadalto-multidecadal scales that are due to internal and external climate variability (Terray, 2012). This variability is called the Atlantic Multidecadal variability (AMV) and has been associated with ocean and atmospheric processes (Delworth et al., 1993; Knight et al., 2005), as well as with volcanic, solar (Otterå et al., 2010) and anthropogenic (Booth et al., 2012) forcing.

There is significant evidence to suggest that the AMV has played an important role in recent trends in tropical precipitation (Kamae et al. 2017) and can substantially modulate the global monsoon (GM) system (Trenberth et al., 2000; Wang \& Ding, 2008; An et al., 2015; Wang et al., 2017, Wang et al., 2018). For example, AMV influences precipitation over North East Brazil and the Sahel by shifting the location of the Intertropical Convergence Zone (ITCZ) over the tropical Atlantic Ocean (Sutton \& Hodson, 2005; Knight et al., 2006). AMV also affects the Indian and the East Asian summer rainfall, through altering the interhemispheric thermal contrast and El-Niño Southern Oscillation (ENSO) variability (Wang et al., 2009; Luo et al., 2017). The positive phase of the AMV can also force an extratropical wavetrain, and can impact the Indian monsoon system (Li et al., 2008). Furthermore, AMV has been linked with changes over the eastern equatorial Pacific Ocean via changes in Walker circulation strength and are also associated with a change in the south Asian summer monsoon (Dong et al., 2006),

Wang et al., (2013) have shown an observed relationship between AMV, the Pacific Ocean and the northern hemisphere summer monsoon. However, the complexity of the climate system and the presence of multiple drivers of the global monsoon makes quantifying AMV's impact difficult, and the involved physical processes remain to be elucidated.

AMV is also composed of SST anomalies in both the tropical and the extratropical North Atlantic Ocean (Sutton \& Hodson, 2007). Generally it is thought that tropical Atlantic anomalies are key to explaining effects of the AMV (Sutton \& Hodson, 2007). However, the subpolar North Atlantic SSTs are highly predictable (Robson et al., 2012), and so could be useful to forecast the effect of AMV over land (Robson et al., 2014). Therefore, it is important to understand the relative effects of SST anomalies in each Atlantic sub-domain, and to understand whether the effects are due to changes in atmospheric 
51 dynamics (i.e. through changes in circulation) or thermodynamics (i.e. through changes in surface 52 temperature and humidity)?

53 In this study we will use idealized modelling experiments to better understand if, and how, the AMV 54 affects the global monsoon (i.e. the tropical monsoon domains). In particular, we will assess the relative 55 roles of dynamic and thermodynamic changes in generating the anomalies, and the linearity of the 56 response. Section 2 outlines the experiments and precipitation decomposition we employ, section 3 57 describes the main results, and the key conclusions are outlined in section 4. 
2.1 MetUM-GOML2 and experimental design

We use the MetUM-GOML2 model to explore the effect of AMV through idealized experiments. MetUM-GOML2 is the Global Ocean Mixed-Layer coupled configuration of the Met Office Unified Model (MetUM-GOML2; Hirons et al. 2015), comprising the MetUM Global Atmosphere 6.0 (Walters et al., 2017) coupled to the Multi-Column K Profile Parameterisation ocean (MC-KPP, version 1.1) via the Ocean Atmosphere Sea Ice Soil (OASIS) coupler (Valcke, 2013). The atmosphere has a 1.87 x $1.25^{\circ}$ horizontal resolution $(\sim 135 \mathrm{~km})$ with 85 vertical levels. The ocean mixed-layer component extends to 1 km depth with 100 vertical levels.

MC-KPP does not allow ocean advection, and also has prescribed SSTs and sea ice concentrations in regions which are not ice-free throughout the year in the reference climatology (i.e. sea ice is not interactive - see coupling mask in figure S1). In coupled regions a seasonally-varying climatological 3D flux correction is applied to both temperature and salinity to hold the model close to a reference ocean climatology. These fluxes represent the mean ocean advection, and account for biases in atmospheric surface heat and freshwater fluxes. Consequently, MetUM-GOML2 has small SST biases and small model drift relative to coupled models with a fully dynamic ocean (Hirons et al., 2015). We use a 1976-2005 mean ocean temperature and salinity reference climatology derived from the Met Office global statistical ocean reanalysis (MOSORA; Smith \& Murphy, 2007). These are used to produce the 3D flux corrections (see Hirons et al, 2015 for details). Outside the coupled region, the atmospheric model is forced by daily SSTs and sea ice from the reference climatology. Anthropogenic greenhouse gas concentrations, aerosol emissions and volcanic activity are imposed and kept constant to their mean value of the period 1976-2005.

We follow a slightly modified form of the experimental design from the Decadal Climate Prediction Project (DCPP; Boer et al. 2016). Specifically, an AMV pattern is imposed in the North Atlantic in the model by modifying non-solar heat fluxes (Figure S1 and methodology in the supplementary material). We perform separate experiments to mimic a positive (hereafter called AMV+) 
and a negative (hereafter called AMV-) phase of the AMV. Unlike in Boer et al. (2016), we multiply the magnitude of the pattern by a factor of two to increase the signal to noise ratio. The targeted pattern is obtained by adding (subtracting) NASST anomalies to (from) the 1976-2005 climatological SSTs and is applied in both coupled and uncoupled regions of the North Atlantic. Note that the additional nonsolar heat flux correction is applied only in the targeted region; outside this, SSTs can vary freely through air-sea interaction. Simulations last for 10 years and 4 months and are initialized on $1^{\text {st }}$ September. Note that the simulations last for 10 years when only the tropical Atlantic is warmed. 15 ensemble members are performed for each experiment using different atmospheric initial conditions.

We have also performed an experiment where NASST are restored to a climatological state, hereafter called CLM. We also test the role of the tropical and extratropical North Atlantic SST anomalies by warming and cooling the Atlantic Ocean south of $30^{\circ} \mathrm{N}$ (hereafter called TNA), and north of $30^{\circ} \mathrm{N}$ (hereafter called XNA), respectively (as defined in DCPP-C, see fig. S1). Finally, we also test the linearity of AMV effects by performing additional experiments with a magnitude of one times AMV (hereafter noted 1xAMV) for both negative and positive phases of the AMV (see table S1).

\subsection{Precipitation metrics}

Global monsoon domains are defined following Wang et al., (2011), selecting land grid points where the annual precipitation range (i.e. the difference between May to September (MJJAS) and

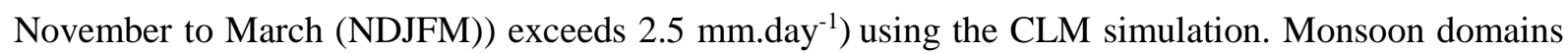
are NAM (North AMerica), NAF (North AFrica), SAS (South ASia) and EAS (East ASia) in the Northern Hemisphere and SAM (South America), SAF (Southern AFrica) and AUS (AUStralia) in the Southern Hemisphere (Figure 1a). We then compute the area-averaged precipitation of each monsoon domain (MI; Monsoon Index). Note that NAF and SAS domains are smaller than in observations due to large dry biases in MetUM-GOML2 over West Africa and India (Figure S2), as also seen in other MetUM configurations (Walters et al., 2017). However, using domains defined from GPCC, or based on an alternative method (i.e. using a relative threshold), does not alter our conclusions (FigS3 and information in the supplementary material). 
surface. Monsoon total precipitation (MP) is the area weighted sum of precipitation in each monsoon domain (Zhou et al., 2008; Hsu et al., 2011; Kitoh et al., 2013). These two metrics complement MI since they quantify the amount of precipitation resulting from changes in both domain size and monsoon intensities. Unlike MI, MA and MP are computed using a dynamic monsoon domain size (i.e. computed for each simulation). and its non-linear cross components $\left(\Delta \mathrm{P}_{\text {cross }}\right)$ following Chadwick et al. (2016). This method relies on the fact that tropical precipitation is dominated by convection (Chadwick et al., 2016; Rowell \& Chadwick, 2018). If precipitation, $P$, is represented as $P=M^{*} q$, where $M^{*}$ is a proxy for convective mass flux from the boundary layer to the free troposphere (Held \& Soden, 2006; Kent et al., 2015) (M* $=P / q)$, and $q$ is near surface specific humidity, then, the change in precipitation, $\Delta P$, can be reformulated

as both specific humidity and circulation. Terms are first calculated using the monthly mean data and for each grid point and then averaged over each season and monsoon domain.

Further decomposition of $\Delta \mathrm{P}_{\text {dyn }}$ allows us to document changes due to shifts in the pattern of circulation $\left(\Delta \mathrm{P}_{\text {shift }}\right)$ or the mean tropical circulation strength $\left(\Delta \mathrm{P}_{\text {strength }}\right)$, as

$$
\Delta \mathrm{P}_{\text {strength }}=\mathrm{q} \Delta \mathrm{M}^{*}{ }_{\text {strength }} \text { and } \Delta \mathrm{P}_{\text {shift }}=\mathrm{q} \Delta \mathrm{M}^{*}{ }_{\text {shift }}
$$
where $\Delta \mathrm{M}^{*}{ }_{\text {strength }}=-\alpha \mathrm{M}^{*}$ with $\alpha=$ tropical mean $\Delta \mathrm{M}^{*} /$ tropical mean $\mathrm{M}^{*}$ represents the change in the strength of the mean tropical circulation. Note that although $\Delta \mathrm{M}^{*}$ is a scalar, $\Delta \mathrm{P}_{\text {strength }}$ is provided for each grid point by multiplying by the reference moisture field. 
Figure 1a shows the observed relationship between AMV and precipitation, and confirms that AMV is associated with significant changes in observed tropical precipitations (Figure S9; (Trenberth \& Shea, 2006; Ting et al., 2011). Figure 1b shows the simulated effect of AMV on precipitation over the summer hemisphere by taking the difference between the AMV+ and AMV-experiments. Positive AMV is associated with a northward shift of the ITCZ over the Atlantic Ocean, leading to increased precipitation in the Northern Hemisphere and decreased precipitation in the Southern Hemisphere (Figure 1b). There are also significant changes in precipitation over the West Pacific warm pool, the northern Indian Ocean and North East India. In contrast, precipitation decreases over northern Australia and Eastern Brazil. As a consequence, precipitation changes are significant over SAM, AUS, NAF and SAS (Figure 1c). However, precipitation changes are not significant for NAM, SAF and EAS, and for GM due to opposing responses between the Northern and the Southern hemispheres. Note the comparison of simulated and observed precipitation patterns highlights differences over the Amazon Basin and over Southern Africa, which we will discuss in section 4.

There are also significant changes in MA and MP (Figure 1d). Monsoon extent is closely linked to changes in total monsoon precipitation in all monsoon domains. In positive AMV, SAM and AUS monsoon domains are considerably smaller, while other monsoon domains become wider, especially SAS, NAF and EAS (Figure 1d and Figure S4).

\subsection{Decomposition of AMV monsoon impacts}

Figure 2 shows the decomposition of monsoon rainfall into dynamic and thermodynamic components, and their nonlinear combination. In most domains $\Delta \mathrm{P}_{\text {dyn }}$ is larger than $\Delta \mathrm{P}_{\text {therm, indicating }}$ that the atmospheric circulation change dominates the impact of AMV on the global monsoons (Figure $2 \mathrm{a}$ and Figure $2 \mathrm{~b}$ ). Moreover, the spatial distribution of $\Delta \mathrm{P}_{\mathrm{dyn}}$ is extremely similar to $\Delta \mathrm{P}$ (Figure $\mathrm{S} 5$ ). $\Delta \mathrm{P}_{\text {therm }}$ exhibits a clear inter-hemispheric pattern, consistent with the surface temperature increase, which 
is mainly confined to the Northern Hemisphere (Figure 3a and Figure 3b). Finally, the nonlinear term tends to increase precipitation in all monsoon domains (Figure 2c). Therefore, the change in precipitation is due to a combination of changes in the three terms. The weak changes in SAM, NAM and EAS precipitation are the result of opposing effects from $\Delta \mathrm{P}_{\mathrm{dyn}}, \Delta \mathrm{P}_{\text {cross }}$ and $\Delta \mathrm{P}_{\text {therm. }}$.

To explore $\Delta \mathrm{P}_{\mathrm{dyn}}$ further, we decompose the circulation response into changes in the mean tropical circulation strength $\left(\Delta \mathrm{P}_{\text {strength }}\right)$ or shifts in atmospheric circulation patterns $\left(\Delta \mathrm{P}_{\text {shift }}\right) . \Delta \mathrm{P}_{\text {strength }}$ is almost negligible, but explains a small increase in precipitation as a response to AMV (Figure 2e). In contrast, $\Delta \mathrm{P}_{\text {shift }}$ is generally larger. Therefore, $\Delta \mathrm{P}_{\mathrm{dyn}}(\mathrm{and}$, hence, $\Delta \mathrm{P})$ is due to a shift in atmospheric circulation, rather than to a modulation of its mean strength (Figure $2 \mathrm{~d}$ ). Moreover, $\Delta \mathrm{P}_{\text {shift }}$ clearly dominates the pattern of $\Delta \mathrm{P}_{\mathrm{dyn}}$ and, by extension, of $\Delta \mathrm{P}$ (Figure S5). The importance of a shift in circulation, on simultaneous changes in both $q$ and $M^{*}$, also helps to explain why $\Delta \mathrm{P}_{\text {cross }}$ plays a significant role.

3.3 AMV's impact on surface temperature and atmospheric circulation

To better understand how AMV affects the global monsoon regions, we analyze changes in surface temperature, $200 \mathrm{hPa}$ velocity potential and low-level wind. In NDJFM and MJJAS the warming of the North Atlantic (Figure 3a and Figure 3b) causes the ITCZ to shift northward, hence increasing NAF precipitation and decreasing precipitation over South America (Knight et al., 2006) through strengthening the Atlantic trade winds (Figure 3e and Figure 3f). Surface temperature also increases over the Eurasian continent in NDJFM and MJJAS, but not over the Indian Ocean (Figure 3a and Figure 3b). Thus, the enhanced South Asian Monsoon is consistent with an increased land-ocean thermal contrast driving a stronger monsoon circulation, as seen in the low-level wind anomalies (Figure 3f) in line with the observations (Wang et al., 2013).

Over Australia and the Maritime Continent, a decrease in winter precipitation is associated with low-level wind divergence (Figure 3e) and increased subsidence over the western Pacific Ocean (Figure 3c). A cooling of the eastern Pacific Ocean and a warming of the western and North Pacific Ocean is consistent with the positive AMV forcing a shift to a negative phase of the Interdecadal Pacific 
Oscillation (IPO) (Zhang et al., 1997; Ruprich-Robert et al., 2017; Figure S6) (Figure 3ab). Here, the cooling in the eastern Pacific Ocean is the result of changes in the Walker circulation forced by anomalously strong ascent over the Atlantic Ocean and India, which are both a result of warming Atlantic SSTs (Figure3 cd). Changes in tropical eastern Pacific temperature in turn impact summer Indian precipitation, as there is a strong relationships between the Indian summer monsoon and ENSO ( Yun \& Timmermann, 2018).

\subsection{Tropical, extratropical warming and linearity of the effects}

We now explore the effects that are driven by tropical or extratropical AMV SSTs. Warming the tropical North Atlantic (TNA) leads to negative anomalies in SAM, and positive anomalies in NAF and SAS precipitation (Figure 4a). The impact of warm TNA SSTs on North East Brazilian and Sahel precipitation is related to anomalously strong cyclonic circulation over the tropical Atlantic and the Caribbean Sea (Figure 4c-d), which leads to divergence over South America and convergence over the equatorial eastern Atlantic Ocean and Sahel. Increased SAS precipitation is associated with a strengthening of the southwesterly Indian monsoon flows, in association with an increase in the interhemispheric thermal gradient and a strengthening of the trade winds (Figure 4d and Figure S7).

A warmer extratropical North Atlantic (XNA) significantly affects the North African Monsoon by shifting the ITCZ northward over western Africa and the Sahel (Figure 4b, consistent with Dunstone et al., 2011). Therefore, both TNA and XNA SST anomalies are important to explain the impacts of AMV on NAF and NAM domains. However, unlike TNA, XNA does not significantly affect the Pacific Ocean, or the Indian Ocean via Walker circulation changes (Figure S6), and, hence, does not affect SAS precipitation. Changes in tropical low-level circulation are also mostly explained by the tropical Atlantic Ocean SSTs, explaining the lack of changes over other monsoon domains in the XNA experiment (Figure 4e-f). Differences in SAS precipitation changes are also associated with differences in the strengthening of the Walker circulation, largely stronger in TNA than in XNA (Figure S8).

We note that the effects of AMV are also non-linear to the magnitude of the Atlantic warming. For example, although the patterns of simulated anomalies are similar (i.e. increase in NAF and SAS and 
decrease in SAM precipitation) the impacts on monsoon precipitation in the AMV experiment are only 1.44 times stronger than in the 1xAMV simulations (Figure 4g; table S2). Furthermore, the sum of TNA and XNA experiments again yields similar anomalies to that of the full AMV experiment, but with a stronger magnitude. Therefore, this non-linearity suggests that there are interference between the response to both TNA and XNA, as proposed in Qasmi et al. (2017).

\section{Conclusions and discussion}

We assessed the effect of the Atlantic Multidecadal Variability (AMV) on global monsoon subdomains in a coupled Atmosphere-Ocean Mixed Layer model (MetUM-GOML2) using idealized SST nudging experiments. Experiments are performed to test the effect of the whole AMV as well as the tropical and extratropical parts of AMV. The key results are as follows

The AMV affects the global monsoon significantly in terms of mean precipitation, total precipitation, and monsoon area. The monsoon strengthens over Northern Africa, and South Asia, and weakens over South America and Australia. However, the effect on the globally integrated monsoon precipitation is not significantly different to zero.

- The effect of AMV on regional monsoons is mostly due to the dynamic response, rather than the thermodynamic response. Furthermore, the dynamical response is due to a shift in the atmospheric circulation, rather than changes in the strength of the mean tropical circulation. For example, a northward shift of the ITCZ over the Atlantic Ocean and a shift to a negative phase of the IPO play a crucial role. This shift in the atmospheric circulation accounts for the important contributions of the nonlinear term.

- The thermodynamic term plays a lesser role but has a significant effect on hemispheric contrast, enhancing (reducing) monsoon precipitation in the northern (southern) hemisphere due to the interhemispheric temperature contrast caused by AMV.

- SST anomalies in the tropical North Atlantic (TNA) explain most of the changes in global monsoons related to the AMV (i.e. decrease in SAM precipitation, increase in NAF and SAS 
precipitation). However, SST anomalies in the extratropical Atlantic also have significant effects, particularly over northern Africa. Therefore, both TNA and XNA must be considered to explain the impact of AMV on the global monsoon variability.

- Changes in the global monsoon are sensitive to the magnitude of the imposed AMV forcing. Experiments with one or two times AMV simulate very similar patterns of precipitation anomalies, but the magnitude of the response is less than two times stronger in the latter than in the former. Similarly, the sum of TNA and XNA experiments yield to an overall stronger precipitation anomaly than the full AMV anomalies.

These results further highlight the important societal effects of AMV, via its significant modulation of tropical precipitation (as seen in Ting et al., 2009b). For instance, a strong and linear relationship is obtained between changes in Monsoon Area and changes in Monsoon Precipitation indicating that in some regions, like SAS, a larger population is impacted by the monsoon during positive phases of AMV. Results also clarify, for the first time, that the atmospheric circulation response is crucial to generate the impact of AMV on the global monsoon subdomains. Additionally, results have highlighted the complex nonlinear nature of AMV impacts in terms of the magnitude of NASST warming and the location of the warming (e.g. over the tropical or the extratropical North Atlantic Ocean).

Although we have shown a significant impact of AMV on the monsoons, there are several caveats. The model is also not able to reproduce the observed link between AMV and SAM or SAF precipitation (Figure S9). For example, MetUM-GOML2 simulates a large decrease in SAM precipitation (Fig. 1b), while observations shows a positive correlation between NASST and winter Amazonian precipitation (Villamayor et al., 2017) (Figure S9). These differences may be related to mean state biases (see Fig. S2). However, comparisons between observations and idealized simulations is not trivial, due to the lack of changes in external forcing or internal variability. Additionally, like most climate models (Schumacher \& Houze, 2003), MetUM-GOML2 overestimates the importance of convective precipitation in the total precipitation (not shown), and uncertainties could remain in decomposing precipitation over the subtropical part of the monsoon domains. Finally, the analysis presented here relies on only one climate model, which does not have a fully dynamic ocean model and, 
267 analysis, as proposed in DCCP-C (Boer et al, 2016).

268

269 
271 Figure 1: (a) Observed precipitation (mm.day ${ }^{-1}$; GPCC; (Schneider et al., 2014)) regressed onto the

272 AMV index (ERSST; (Huang et al., 2015)) (See the method in the supplementary material). (b) Change 273 in precipitation $\left(\mathrm{mm} . \mathrm{day}^{-1}\right)$ related to AMV (AMV+ minus AMV-). Monsoon domains are drawn in red 274 (see section 2.2 for details). Precipitation anomalies are shown for MJJAS (NDJFM) for the Northern (Southern) Hemisphere. Stippling indicates that anomalies are significantly different to zero according to a Student's t-test at the $95 \%$ confidence level. (c) Changes in monsoon index (MI; mm.day ${ }^{-1}$ ) for AMV+ minus AMV-. A blue bar indicates significant changes according to a Student's t-test at the 95\% confidence level. Orange vertical lines show two standard errors. (d) Change in monsoon area (MA; \% of the Earth total surface) versus the change in monsoon precipitation (MP; total area weighed precipitation, in $10^{9} \mathrm{~m}^{3}$. day ${ }^{-1}$ ). Vertical and horizontal colored lines indicate two standard errors for both MP and MA. The black line is the MA-MP linear regression (excluding GM). For (c) monsoon domains are not fixed and computed separately from each member and experiment.

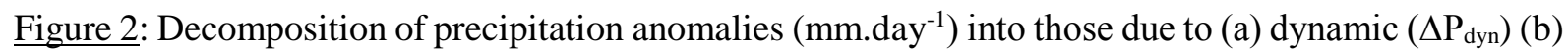
thermodynamic $\left(\Delta \mathrm{P}_{\text {therm }}\right)$ and (c) cross-term $\left(\Delta \mathrm{P}_{\text {cross }}\right)$ terms, as defined in Chadwick et al. (2016). The dynamic part is decomposed into its (e) shift $\left(\Delta \mathrm{P}_{\text {shift }}\right.$, i.e. due to a change in the pattern of the circulation) and (f) weak ( $\Delta \mathrm{P}_{\text {strength, }}$ i.e. related to the strength of the mean tropical circulation) components. Orange vertical lines represent two standard errors. A blue bar is added when anomalies are stronger than two standard errors.

Figure 3: Effect of AMV on (top panels) surface temperature $\left({ }^{\circ} \mathrm{C}\right.$ ), (middle) $250 \mathrm{hPa}$ velocity potential (in $10^{4} \mathrm{~m}^{2} \mathrm{~s}^{-1}$ ) and divergent wind $\left(\mathrm{m} . \mathrm{s}^{-1}\right)$ and (bottom) sea level pressure (Pa) and $850 \mathrm{hPa}$ wind (m.s ${ }^{1}$ ), in (left) NDJFM and (right) MJJAS. Stippling (shading) for surface temperature (velocity potential) indicates that changes are significantly different to zero according to a Student's t-test at the 95\% confidence level. For the $850 \mathrm{hPa}$ wind, arrows are drawn only if their meridional or zonal components are significantly different to zero, according to a Student's t-test at the $95 \%$ confidence level.

Figure 4: Top panels: same as in figure $1 \mathrm{~b}$ but for (a) the tropical Atlantic Ocean warming (TNA+ minus TNA-) and (b) due to the extratropical Atlantic Ocean warming (XNA+ minus XNA-). Middle panels: same as in figure $3 \mathrm{a}$ and figure $3 \mathrm{~b}$, but for TNA and XNA. Bottom panels: effect of 2xAMV on MI in function of the effect of (left) 1xAMV on MI (right) the TNA+XNA sum on MI. Vertical and horizontal black lines indicate the spread in MI, and the black line is the linear regression, as computed from the sub-domain monsoons only (e.g. excluding GM). Significance in panels a-f are calculated using a Student's t-test at the $95 \%$ confidence level. 
Acknowledgements The authors gratefully acknowledge support from the UK-China Research and Innovation Partnership Fund through the Met Office Climate Science for Service Partnership (CSSP) China as part of the Newton Fund. BD, DH and JR were supported by the Natural Environment Research Council (NERC) via the National Centre for Atmospheric Science (NCAS), and JR was additionally funded by the NERC ACSIS program. NK was supported by a NERC Independent Research Fellowship (NE/L010976/1). Assembly of MetUM-GOML and development of MC-KPP was supported by the National Centre for Atmospheric Science and led by Dr. Nicholas Klingaman. The authors thank the two anonymous reviewers for their constructive comments and suggestions. The data set used for this study is freely available on http://doi.org/10.5281/zenodo.2386272. Additional data will be available through the EU PRIMAVERA project and will be published in due course at BADC via ESGF.

\section{Plain language summary}

Global monsoon precipitation variability has substantial effects on about two-thirds of the world's population. Therefore, understanding the factors that drive tropical precipitation is societally important. Here we focus on the effect of North Atlantic Sea Surface Temperature (NASST) variability on global monsoon. To do so we use a set of climate model experiments, in which we add a surface temperature anomaly over the North Atlantic Ocean. The novelty of the analysis relies on the decomposition of precipitation changes to understand better their origins. We find that NASST changes have strong impacts on Sahel and Indian summer precipitation and monsoon domain sizes, through shifting northward the atmospheric patterns of moisture convergence. Changes involve increases in the largescale warming of the northern Hemisphere and forcing of the eastern equatorial Pacific Ocean temperature. We highlight the tropical Atlantic basin as critical to explain the effects of NASST variability over the global monsoon. We found that changes in monsoon precipitation are sensitive to the magnitude of the NASST warming. 
An, Z., Wu, G., Li, J., Sun, Y., Liu, Y., Zhou, W., et al. (2015). Global Monsoon Dynamics and Climate Change. Annual Review of Earth and Planetary Sciences, 43(1), 29-77. JOUR. https://doi.org/10.1146/annurev-earth-060313-054623

Ba, J., Keenlyside, N. S., Latif, M., Park, W., Ding, H., Lohmann, K., et al. (2014). A multi-model comparison of Atlantic multidecadal variability. Climate Dynamics, 43(9), 2333-2348. article. https://doi.org/10.1007/s00382-014-2056-1

Bellomo, K., Murphy, L. N., Cane, M. A., Clement, A. C., \& Polvani, L. M. (2017). Historical forcings as main drivers of the Atlantic multidecadal variability in the CESM large ensemble. Climate Dynamics. article. https://doi.org/10.1007/s00382-017-3834-3

Boer, G. J., Smith, D. M., Cassou, C., Doblas-Reyes, F., Danabasoglu, G., Kirtman, B., et al. (2016). The Decadal Climate Prediction Project (DCPP) contribution to CMIP6. Geoscientific Model Development, 9(10), 3751-3777. article. https://doi.org/10.5194/gmd-9-3751-2016

Booth, B. B. B., Dunstone, N. J., Halloran, P. R., Andrews, T., \& Bellouin, N. (2012). Aerosols implicated as a prime driver of twentieth-century North Atlantic climate variability. Nature, 484(7393), 228-232. https://doi.org/10.1038/nature10946

Chadwick, R., Good, P., \& Willett, K. (2016). A Simple Moisture Advection Model of Specific Humidity Change over Land in Response to SST Warming. Journal of Climate, 29(21), 76137632. JOUR. https://doi.org/10.1175/JCLI-D-16-0241.1

Clement, A., Bellomo, K., Murphy, L. N., Cane, M. A., Mauritsen, T., Rädel, G., \& Stevens, B. (2015). The Atlantic Multidecadal Oscillation without a role for ocean circulation. Science, 350(6258), 320-324. article. https://doi.org/10.1126/science.aab3980

Delworth, T., \& Mann, M. (2000). Observed and simulated multidecadal variability in the Northern Hemisphere. Climate Dynamics, 16(9), 661-676. article. https://doi.org/10.1007/s003820000075

Delworth, T. L., Manabe, S., \& Stouffer, R. J. (1993). Interdecadal Variations of the Thermohaline Circulation in a Coupled Ocean-Atmosphere Model. Journal of Climate, 6(11), 1993-2011. JOUR. https://doi.org/10.1175/1520-0442(1993)006<1993:IVOTTC>2.0.CO;2

Dong, B., Sutton, R. T., \& Scaife, A. A. (2006). Multidecadal modulation of El Niño-Southern Oscillation (ENSO) variance by Atlantic Ocean sea surface temperatures. Geophysical Research Letters, 33(8). JOUR. https://doi.org/10.1029/2006GL025766

Dunstone, N. J., Smith, D. M., \& Eade, R. (2011). Multi-year predictability of the tropical Atlantic atmosphere driven by the high latitude North Atlantic Ocean. Geophysical Research Letters, 38(14), n/a--n/a. article. https://doi.org/10.1029/2011GL047949

Held, I. M., \& Soden, B. J. (2006). Robust Responses of the Hydrological Cycle to Global Warming. Journal of Climate, 19(21), 5686-5699. JOUR. https://doi.org/10.1175/JCLI3990.1

Hirons, L. C., Klingaman, N. P., \& Woolnough, S. J. (2015). MetUM-GOML: a near-globally coupled atmosphere-ocean-mixed-layer model. Geoscientific Model Development, 8, 363-379. JOUR.

Hsu, P., Li, T., \& Wang, B. (2011). Trends in global monsoon area and precipitation over the past 30 years. Geophysical Research Letters, 38(8). JOUR. https://doi.org/doi:10.1029/2011GL046893

Huang, B., Banzon, V. F., Freeman, E., Lawrimore, J., Liu, W., Peterson, T. C., et al. (2015). Extended Reconstructed Sea Surface Temperature Version 4 (ERSST.v4). Part I: Upgrades and 
Intercomparisons. Journal of Climate, 28(3), 911-930. article. https://doi.org/10.1175/JCLI-D$14-00006.1$

Kamae, Y., Li, X., Xie, S.-P., \& Ueda, H. (2017). Atlantic effects on recent decadal trends in global monsoon. Climate Dynamics. article. https://doi.org/10.1007/s00382-017-3522-3

Kent, C., Chadwick, R., \& Rowell, D. P. (2015). Understanding Uncertainties in Future Projections of Seasonal Tropical Precipitation. Journal of Climate, 28(11), 4390-4413. JOUR. https://doi.org/10.1175/JCLI-D-14-00613.1

Kitoh, A., Endo, H., Krishna Kumar, K., Cavalcanti, I. F. A., Goswami, P., \& Zhou, T. (2013). Monsoons in a changing world: A regional perspective in a global context. Journal of Geophysical Research: Atmospheres, 118(8), 3053-3065. article. https://doi.org/10.1002/jgrd.50258

Knight, J. R., Allan, R. J., Folland, C. K., Vellinga, M., \& Mann, M. E. (2005). A signature of persistent natural thermohaline circulation cycles in observed climate. Geophysical Research Letters, 32(20), n/a--n/a. article. https://doi.org/10.1029/2005GL024233

Knight, J. R., Folland, C. K., \& Scaife, A. A. (2006). Climate impacts of the Atlantic Multidecadal Oscillation. Geophysical Research Letters, 33(17), L17706. https://doi.org/10.1029/2006GL026242

Kucharski, F., Kang, I.-S., Farneti, R., \& Feudale, L. (2011). Tropical Pacific response to 20th century Atlantic warming. Geophysical Research Letters, 38(3). JOUR. https://doi.org/10.1029/2010GL046248

Li, S., Perlwitz, J., Quan, X., \& Hoerling, M. P. (2008). Modelling the influence of North Atlantic multidecadal warmth on the Indian summer rainfall. Geophysical Research Letters, 35(5). article. https://doi.org/10.1029/2007GL032901

Luo, F., Li, S., Gao, Y., Keenlyside, N., Svendsen, L., \& Furevik, T. (2017). The connection between the Atlantic multidecadal oscillation and the Indian summer monsoon in CMIP5 models. Climate Dynamics. JOUR. https://doi.org/10.1007/s00382-017-4062-6

Martin, E. R., \& Thorncroft, C. D. (2014). The impact of the AMO on the West African monsoon annual cycle. Quarterly Journal of the Royal Meteorological Society, 140(678), 31-46. https://doi.org/10.1002/qj.2107

McGregor, S., Timmermann, A., Stuecker, M. F., England, M. H., Merrifield, M., Jin, F.-F., \& Chikamoto, Y. (2014). Recent Walker circulation strengthening and Pacific cooling amplified by Atlantic warming. Nature Climate Change, 4, 888. JOUR. Retrieved from http://dx.doi.org/10.1038/nclimate2330

Msadek, R., Delworth, T. L., Rosati, A., Anderson, W., Vecchi, G., Chang, Y.-S., et al. (2014). Predicting a Decadal Shift in North Atlantic Climate Variability Using the GFDL Forecast System. Journal of Climate, 27(17), 6472-6496. https://doi.org/10.1175/JCLI-D-13-00476.1

Otterå, O. H., Bentsen, M., Drange, H., \& Suo, L. (2010). External forcing as a metronome for Atlantic multidecadal variability. Nature Geoscience, 3, 688. JOUR. Retrieved from http://dx.doi.org/10.1038/ngeo955

Robson, J., Sutton, R., \& Smith, D. (2014). Decadal predictions of the cooling and freshening of the North Atlantic in the 1960s and the role of ocean circulation. Climate Dynamics, 42(9-10), 2353-2365. https://doi.org/10.1007/s00382-014-2115-7

Robson, J. I., Sutton, R. T., \& Smith, D. M. (2012). Initialized decadal predictions of the rapid warming of the North Atlantic Ocean in the mid 1990s. Geophysical Research Letters, 39(19), 
Rowell, D. P., \& Chadwick, R. (2018). Causes of the Uncertainty in Projections of Tropical Terrestrial Rainfall Change: East Africa. Journal of Climate. JOUR. https://doi.org/10.1175/JCLI-D-170830.1

Ruprich-Robert, Y., Msadek, R., Castruccio, F., Yeager, S., Delworth, T., \& Danabasoglu, G. (2017). Assessing the Climate Impacts of the Observed Atlantic Multidecadal Variability Using the GFDL CM2.1 and NCAR CESM1 Global Coupled Models. Journal of Climate, 30(8), 27852810. JOUR. https://doi.org/10.1175/JCLI-D-16-0127.1

Schneider, U., Becker, A., Finger, P., Meyer-Christoffer, A., Ziese, M., \& Rudolf, B. (2014). GPCC's new land surface precipitation climatology based on quality-controlled in situ data and its role in quantifying the global water cycle. Theoretical and Applied Climatology, 115(1-2), 15-40. https://doi.org/10.1007/s00704-013-0860-x

Schumacher, C., \& Houze, R. A. (2003). Stratiform Rain in the Tropics as Seen by the TRMM Precipitation Radar. Journal of Climate, 16(11), 1739-1756. JOUR. https://doi.org/10.1175/1520-0442(2003)016<1739:SRITTA>2.0.CO;2

Smith, D. M., \& Murphy, J. M. (2007). An objective ocean temperature and salinity analysis using covariances from a global climate model. Journal of Geophysical Research, 112(C2), C02022. https://doi.org/10.1029/2005JC003172

Sutton, R., \& Hodson, D. (2007). Climate Response to Basin-Scale Warming and Cooling of the North Atlantic Ocean. Journal of Climate, 20(5), 891-907. JOUR. https://doi.org/10.1175/JCLI4038.1

Sutton, R. T., \& Hodson, D. L. R. (2005). Atlantic Ocean Forcing of North American and European Summer Climate. Science, 309(5731), 115-118. article. https://doi.org/10.1126/science.1109496

Terray, L. (2012). Evidence for multiple drivers of North Atlantic multi-decadal climate variability. Geophysical Research Letters, 39(19). article. https://doi.org/10.1029/2012GL053046

Ting, M., Kushnir, Y., Seager, R., \& Li, C. (2009). Forced and Internal Twentieth-Century SST Trends in the North Atlantic. Journal of Climate, 22(6), 1469-1481. article. https://doi.org/10.1175/2008JCLI2561.1

Ting, M., Kushnir, Y., Seager, R., \& Li, C. (2011). Robust features of Atlantic multi-decadal variability and its climate impacts. Geophysical Research Letters, 38(17). JOUR. https://doi.org/10.1029/2011GL048712

Trenberth, K. E., \& Shea, D. J. (2006). Atlantic hurricanes and natural variability in 2005. Geophysical Research Letters, 33(12). article. https://doi.org/10.1029/2006GL026894

Trenberth, K. E., Stepaniak, D. P., \& Caron, J. M. (2000). The Global Monsoon as Seen through the Divergent Atmospheric Circulation. Journal of Climate, 13(22), 3969-3993. JOUR. https://doi.org/10.1175/1520-0442(2000)013<3969:TGMAST>2.0.CO;2

Valcke, S. (2013). The OASIS3 coupler: a European climate modelling community software. Geoscientific Model Development, 6(2), 373-388. https://doi.org/10.5194/gmd-6-373-2013

Villamayor, J., Ambrizzi, T., \& Mohino, E. (2017). Influence of decadal sea surface temperature variability on northern Brazil rainfall in CMIP5 simulations. Climate Dynamics. JOUR. https://doi.org/10.1007/s00382-017-3941-1

Walters, D., Boutle, I., Brooks, M., Melvin, T., Stratton, R., Vosper, S., et al. (2017). The Met Office Unified Model Global Atmosphere 6.0/6.1 and JULES Global Land 6.0/6.1 configurations. Geoscientific Model Development, 10(4), 1487-1520. article. https://doi.org/10.5194/gmd-10- 
Wang, B., \& Ding, Q. (2008). Global monsoon: Dominant mode of annual variation in the tropics. Dynamics of Atmospheres and Oceans, 44(3), 165-183. JOUR. https://doi.org/https://doi.org/10.1016/j.dynatmoce.2007.05.002

Wang, B., Kim, H.-J., Kikuchi, K., \& Kitoh, A. (2011). Diagnostic metrics for evaluation of annual and diurnal cycles. Climate Dynamics, 37(5), 941-955. JOUR. https://doi.org/10.1007/s00382010-0877-0

Wang, B., Liu, J., Kim, H.-J., Webster, P. J., Yim, S.-Y., \& Xiang, B. (2013). Northern Hemisphere summer monsoon intensified by mega-El Niño/southern oscillation and Atlantic multidecadal oscillation. Proceedings of the National Academy of Sciences, 110(14), 5347 LP-5352. JOUR. Retrieved from http://www.pnas.org/content/110/14/5347.abstract

Wang, B., Li, J., Cane, M. A., Liu, J., Webster, P. J., Xiang, B., et al. (2018). Toward Predicting Changes in the Land Monsoon Rainfall a Decade in Advance. Journal of Climate, 31(7), 26992714. JOUR. https://doi.org/10.1175/JCLI-D-17-0521.1

Wang, P. X., Wang, B., Cheng, H., Fasullo, J., Guo, Z., Kiefer, T., \& Liu, Z. (2017). The global monsoon across time scales: Mechanisms and outstanding issues. Earth-Science Reviews, 174, 84-121. JOUR. https://doi.org/https://doi.org/10.1016/j.earscirev.2017.07.006

Wang, Y., Li, S., \& Luo, D. (2009). Seasonal response of Asian monsoonal climate to the Atlantic Multidecadal Oscillation. Journal of Geophysical Research: Atmospheres, 114(D2). JOUR. https://doi.org/10.1029/2008JD010929

Yeager, S., Karspeck, A., Danabasoglu, G., Tribbia, J., Teng, H., Yeager, S., et al. (2012). A Decadal Prediction Case Study: Late Twentieth-Century North Atlantic Ocean Heat Content. Journal of Climate, 25(15), 5173-5189. https://doi.org/10.1175/JCLI-D-11-00595.1

Yun, K.-S., \& Timmermann, A. (2018). Decadal Monsoon-ENSO Relationships Reexamined. Geophysical Research Letters, 45(4), 2014-2021. JOUR. https://doi.org/10.1002/2017GL076912

Zhang, R., \& Delworth, T. L. (2006). Impact of Atlantic multidecadal oscillations on India/Sahel rainfall and Atlantic hurricanes. Geophysical Research Letters, 33(17). JOUR. https://doi.org/10.1029/2006GL026267

Zhang, Y., Wallace, J. M., \& Battisti, D. S. (1997). ENSO-like Interdecadal Variability: 1900-93. Journal of Climate, 10(5), 1004-1020. JOUR. https://doi.org/10.1175/15200442(1997)010<1004:ELIV>2.0.CO;2

Zhou, T., Zhang, L., \& Li, H. (2008). Changes in global land monsoon area and total rainfall accumulation over the last half century. Geophysical Research Letters, 35(16). JOUR. https://doi.org/doi:10.1029/2008GL034881 
a)

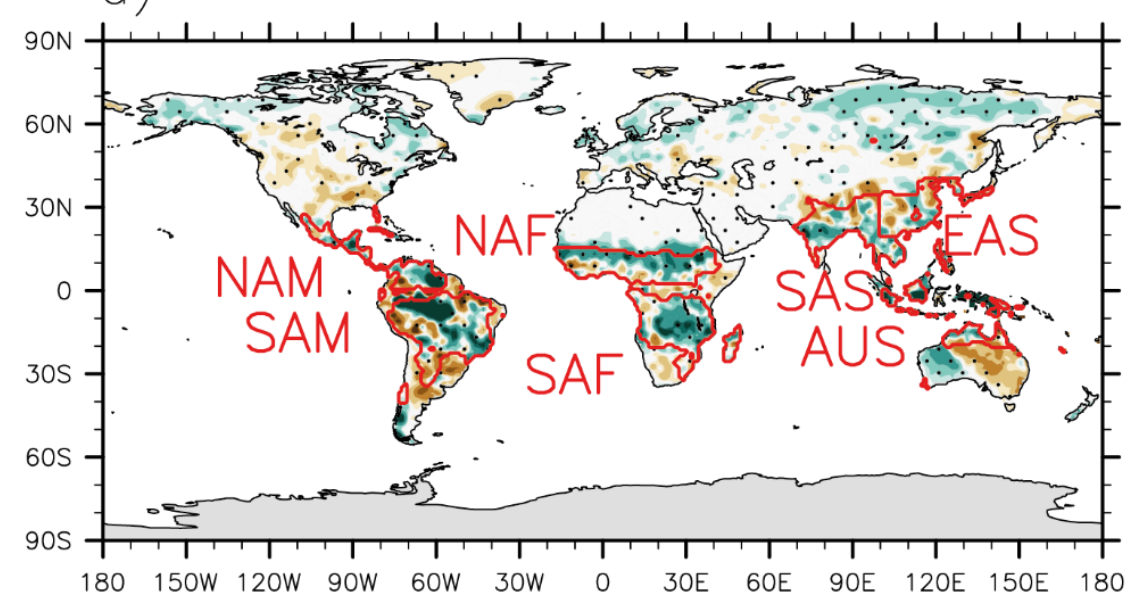

b)
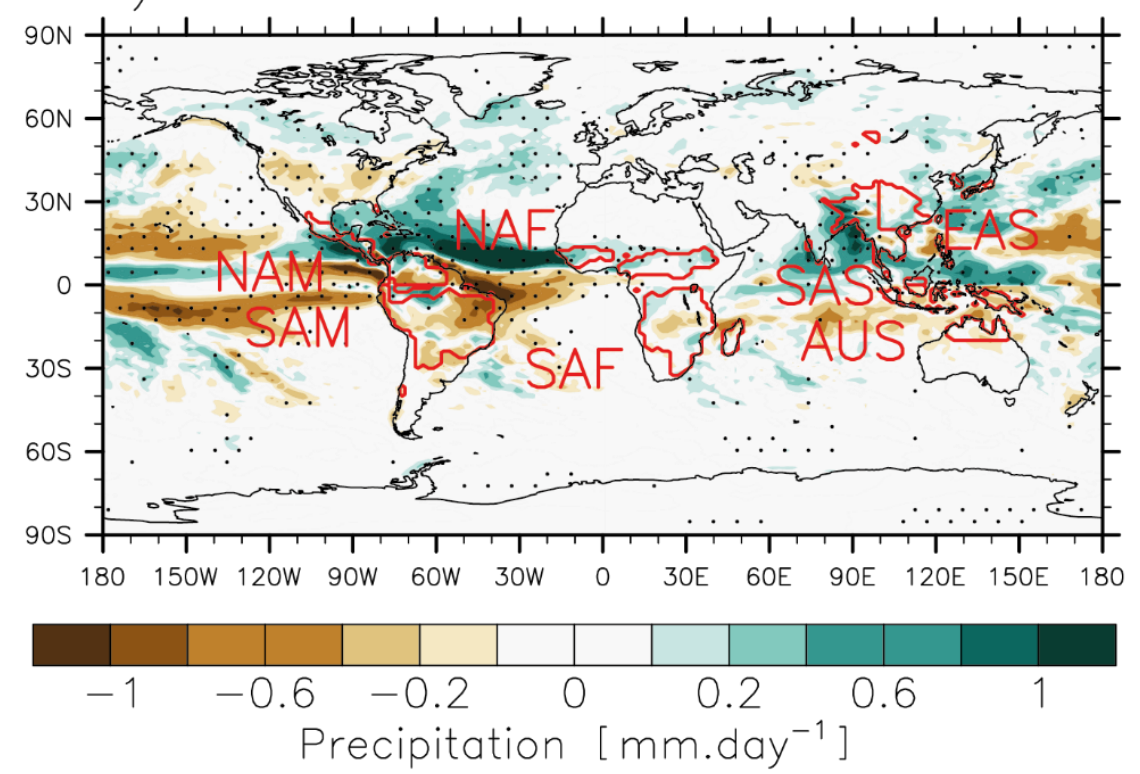

c)

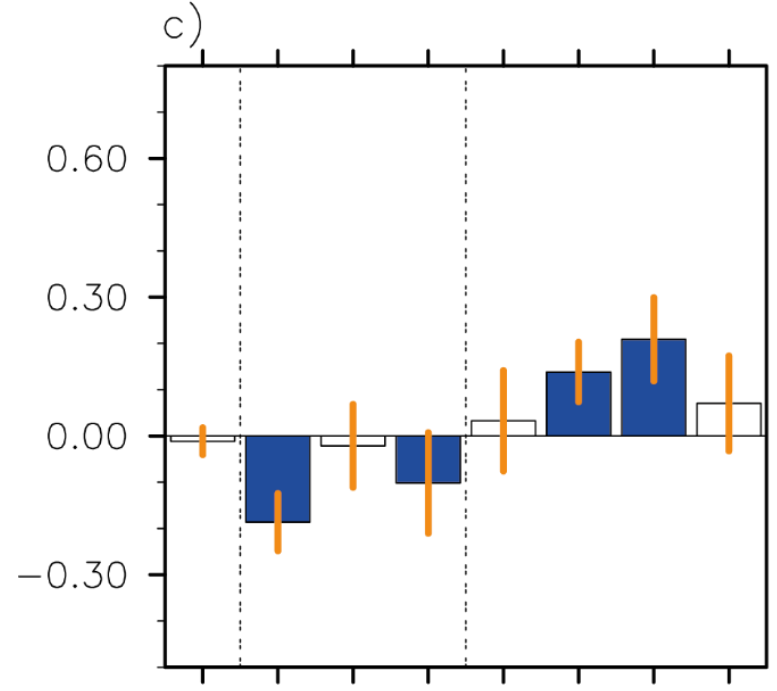

GM SAMSAF AUSNAMNAF SASEAS

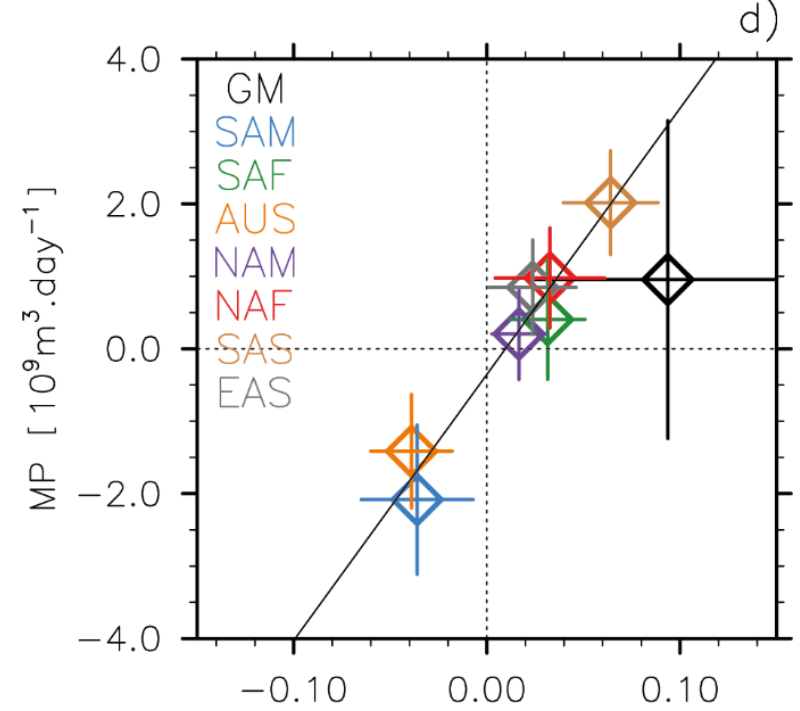

MA [\% of Earth total surface]

Figure 1: (a) Observed precipitation (mm.day ${ }^{-1}$; GPCC; (Schneider et al., 2014)) regressed onto the AMV index (ERSST;(Huang et al., 2015)) (See the method in the supplementary material). (b) Change in precipitation $\left(\mathrm{mm}^{-} \mathrm{day}^{-1}\right)$ related to AMV (AMV+ minus AMV-). Monsoon domains are drawn in red 
500 (see section 2.2 for details). Precipitation anomalies are shown for MJJAS (NDJFM) for the Northern 501 (Southern) Hemisphere. Stippling indicates that anomalies are significantly different to zero according to a Student's t-test at the $95 \%$ confidence level. (c) Changes in monsoon index (MI; mm.day ${ }^{-1}$ ) for AMV+ minus AMV-. A blue bar indicates significant changes according to a Student's t-test at the 95\% confidence level. Orange vertical lines show two standard errors. (d) Change in monsoon area (MA; \% of the Earth total surface) versus the change in monsoon precipitation (MP; total area weighed precipitation, in $10^{9} \mathrm{~m}^{3}$.day ${ }^{-1}$ ). Vertical and horizontal colored lines indicate two standard errors for both MP and MA. The black line is the MA-MP linear regression (excluding GM). For (c) monsoon domains are not fixed and computed separately from each member and experiment. 

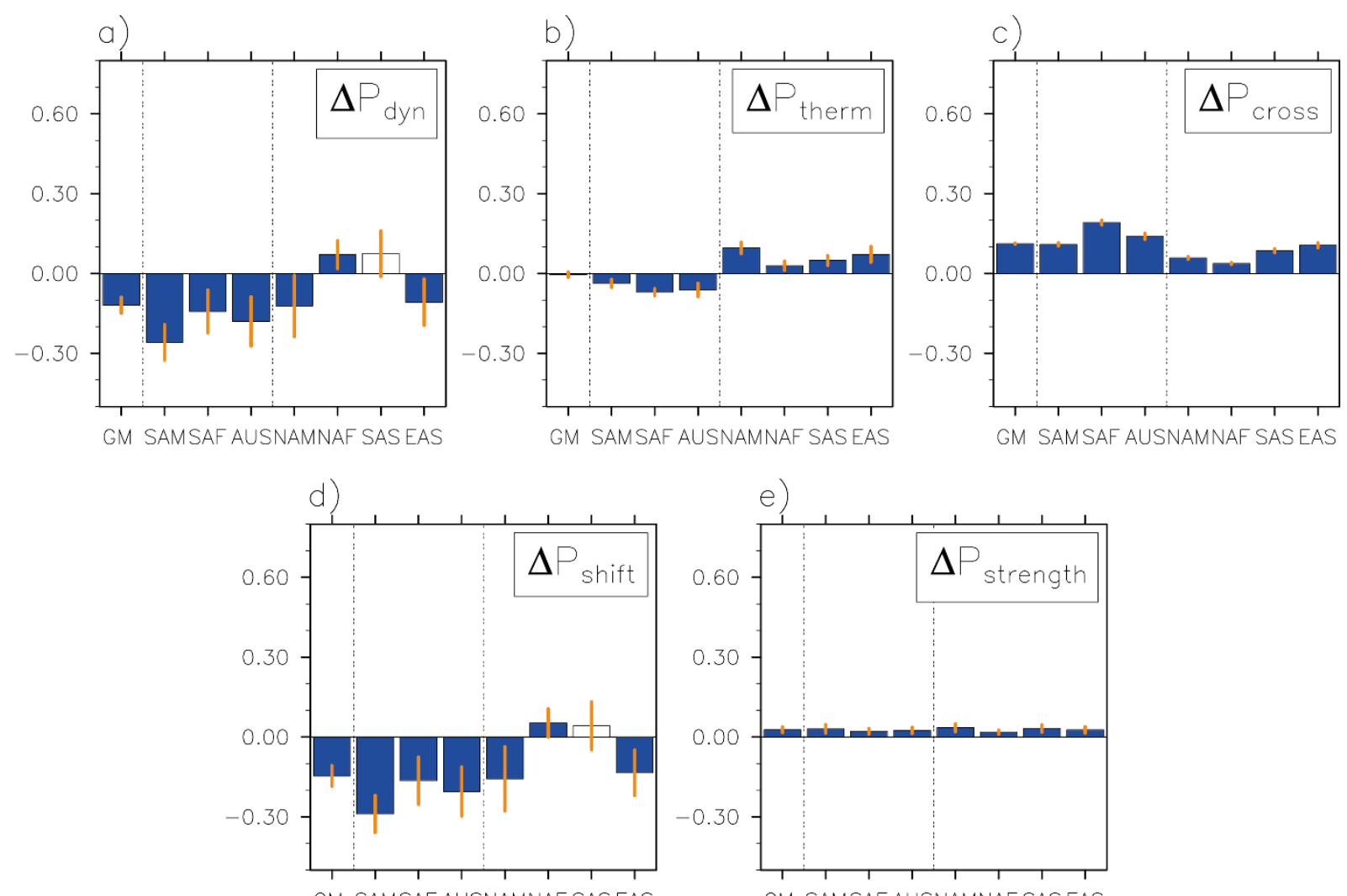

Figure 2: Decomposition of precipitation anomalies $\left(\mathrm{mm}^{-d a y}{ }^{-1}\right)$ into those due to (a) dynamic $\left(\Delta \mathrm{P}_{\text {dyn }}\right)\left(\right.$ b) thermodynamic $\left(\Delta \mathrm{P}_{\text {therm }}\right)$ and (c) cross-term $\left(\Delta \mathrm{P}_{\text {cross }}\right)$ terms, as defined in Chadwick et al. (2016). The dynamic part is decomposed into its (e) shift $\left(\Delta \mathrm{P}_{\text {shift, }}\right.$, i.e. due to a change in the pattern of the circulation) and (f) weak ( $\Delta \mathrm{P}_{\text {strength, }}$, i.e. related to the strength of the mean tropical circulation) components. Orange vertical lines represent two standard errors. A blue bar is added when anomalies are stronger than two standard errors. 
a)

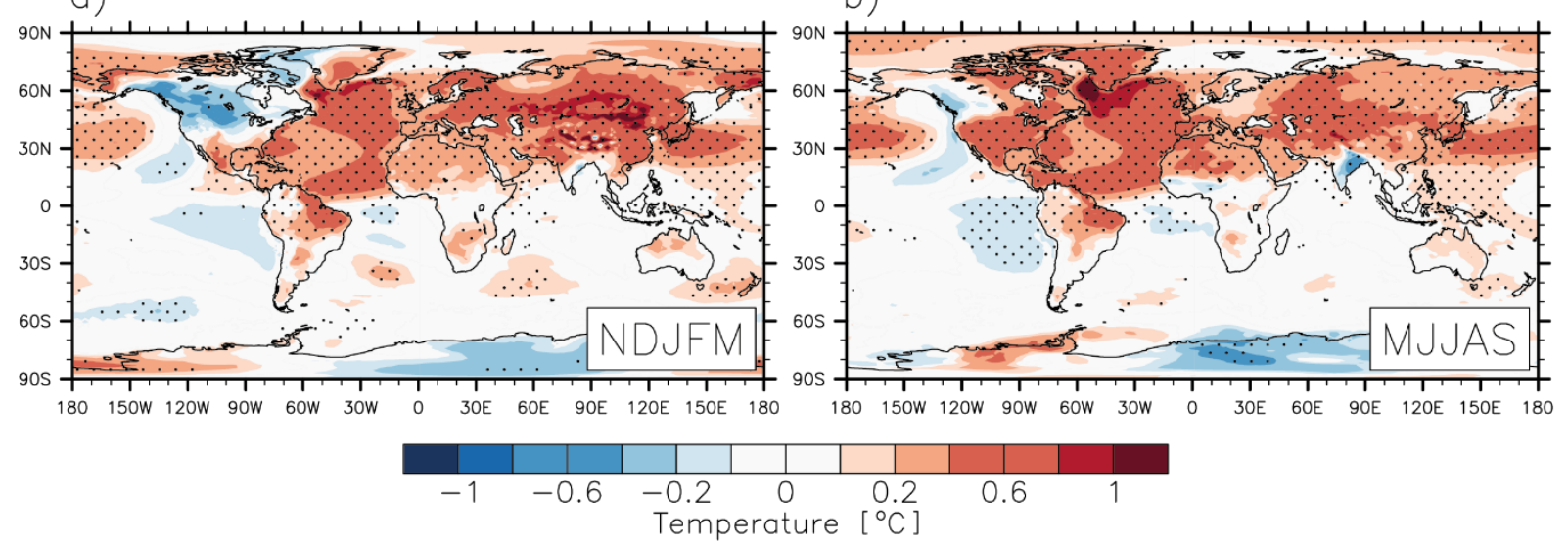

c)

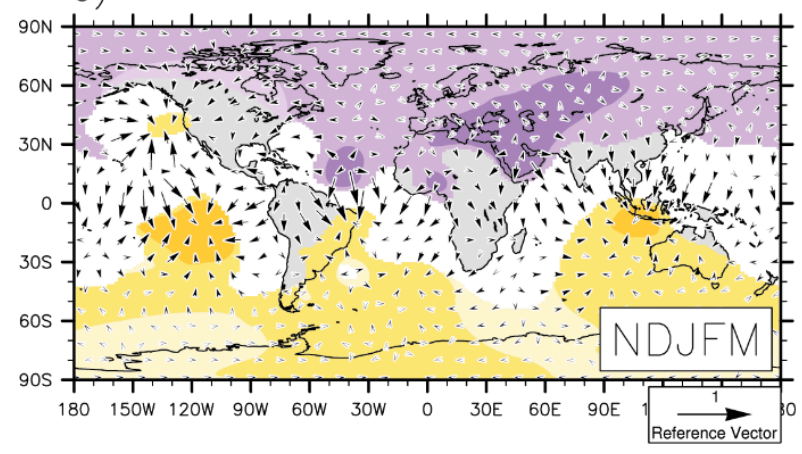

d)

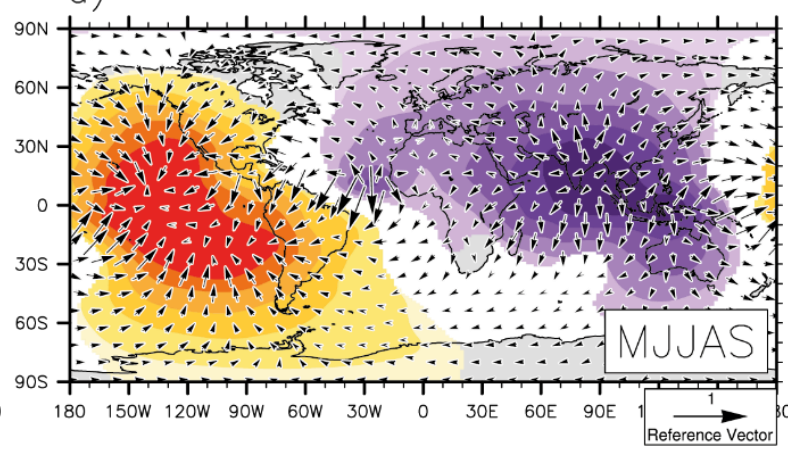

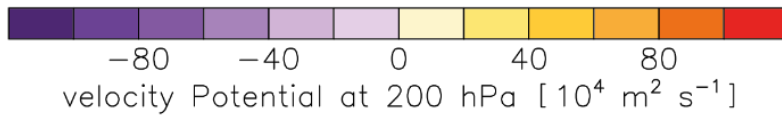

e)
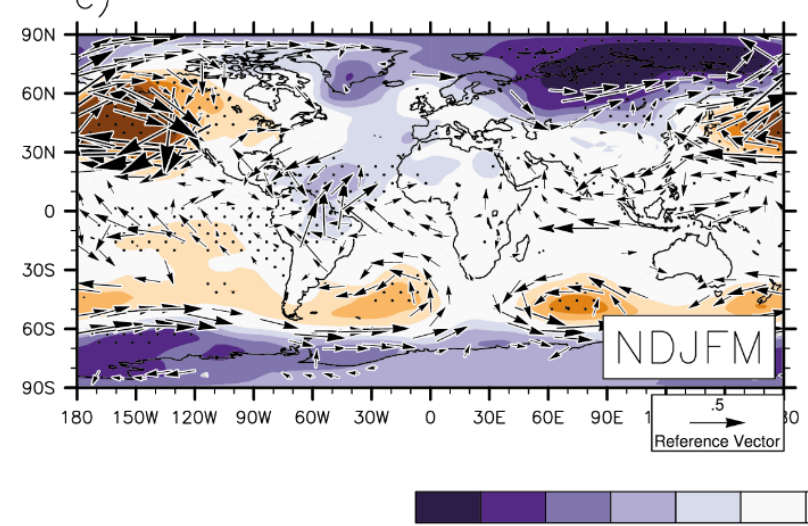

f)

Figure 3: Effect of AMV on (top panels) surface temperature $\left({ }^{\circ} \mathrm{C}\right.$ ), (middle) $250 \mathrm{hPa}$ velocity potential (in $\left.10^{4} \mathrm{~m}^{2} \mathrm{~s}^{-1}\right)$ and divergent wind $\left(\mathrm{m} . \mathrm{s}^{-1}\right)$ and (bottom) sea level pressure (Pa) and $850 \mathrm{hPa}$ wind $\left(\mathrm{m} . \mathrm{s}^{-}\right.$ ${ }^{1}$ ), in (left) NDJFM and (right) MJJAS. Stippling (shading) for surface temperature (velocity potential) indicates that changes are significantly different to zero according to a Student's t-test at the 95\% confidence level. For the $850 \mathrm{hPa}$ wind, arrows are drawn only if their meridional or zonal components are significantly different to zero, according to a Student's t-test at the $95 \%$ confidence level. 
a)

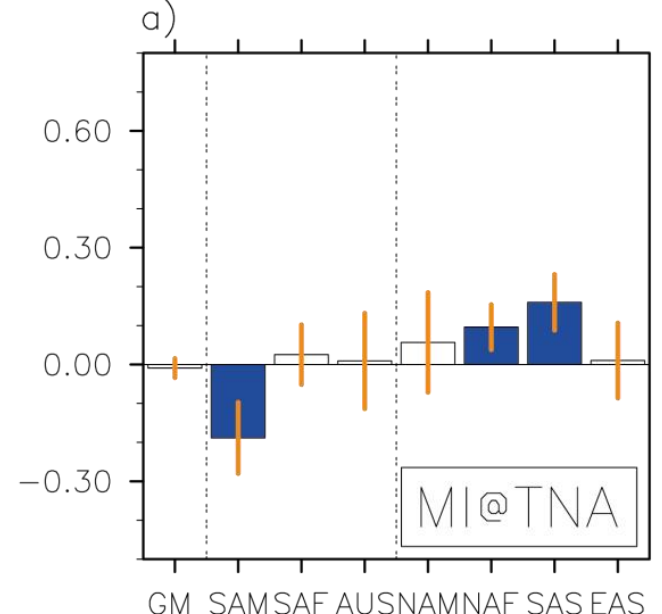

c)

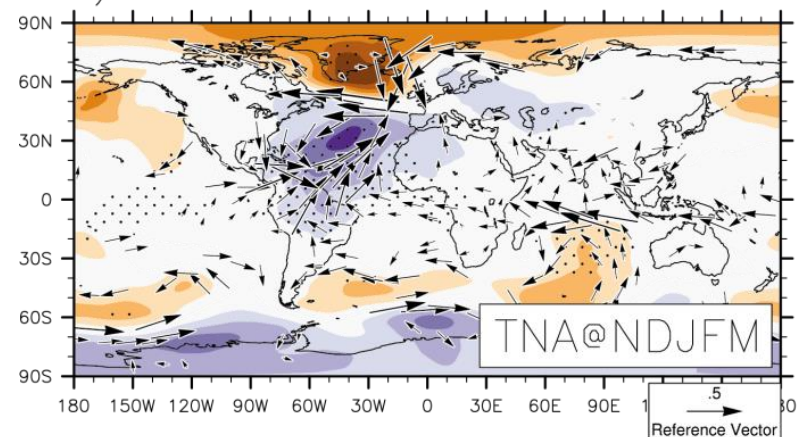

e)

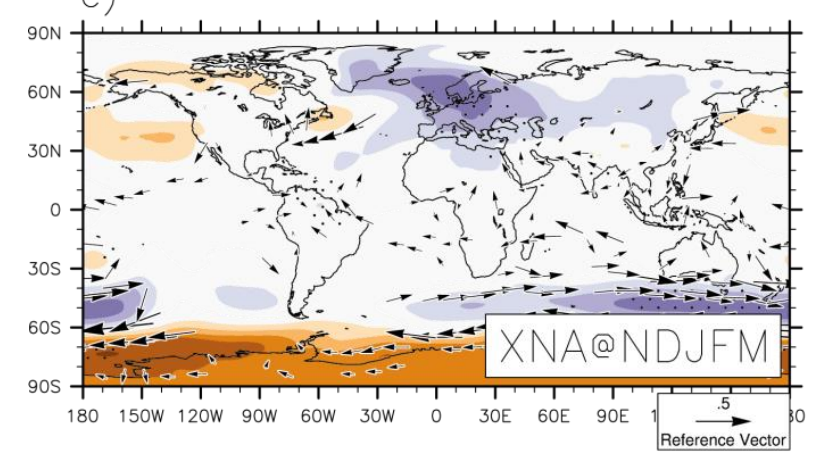

b)

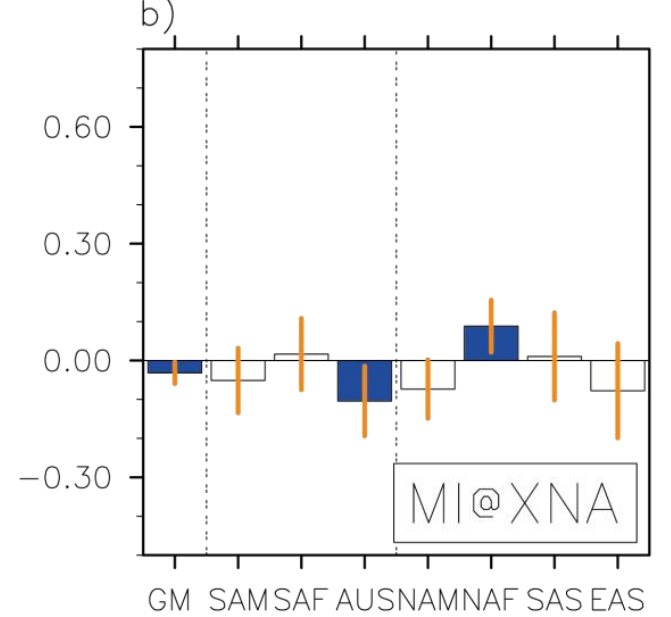

d)

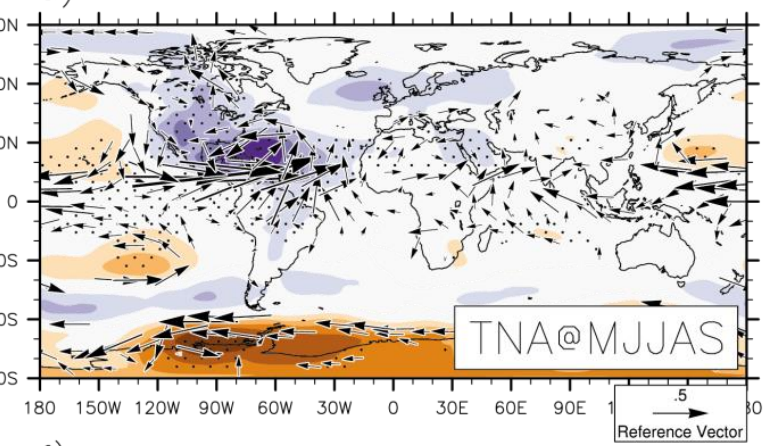

f)
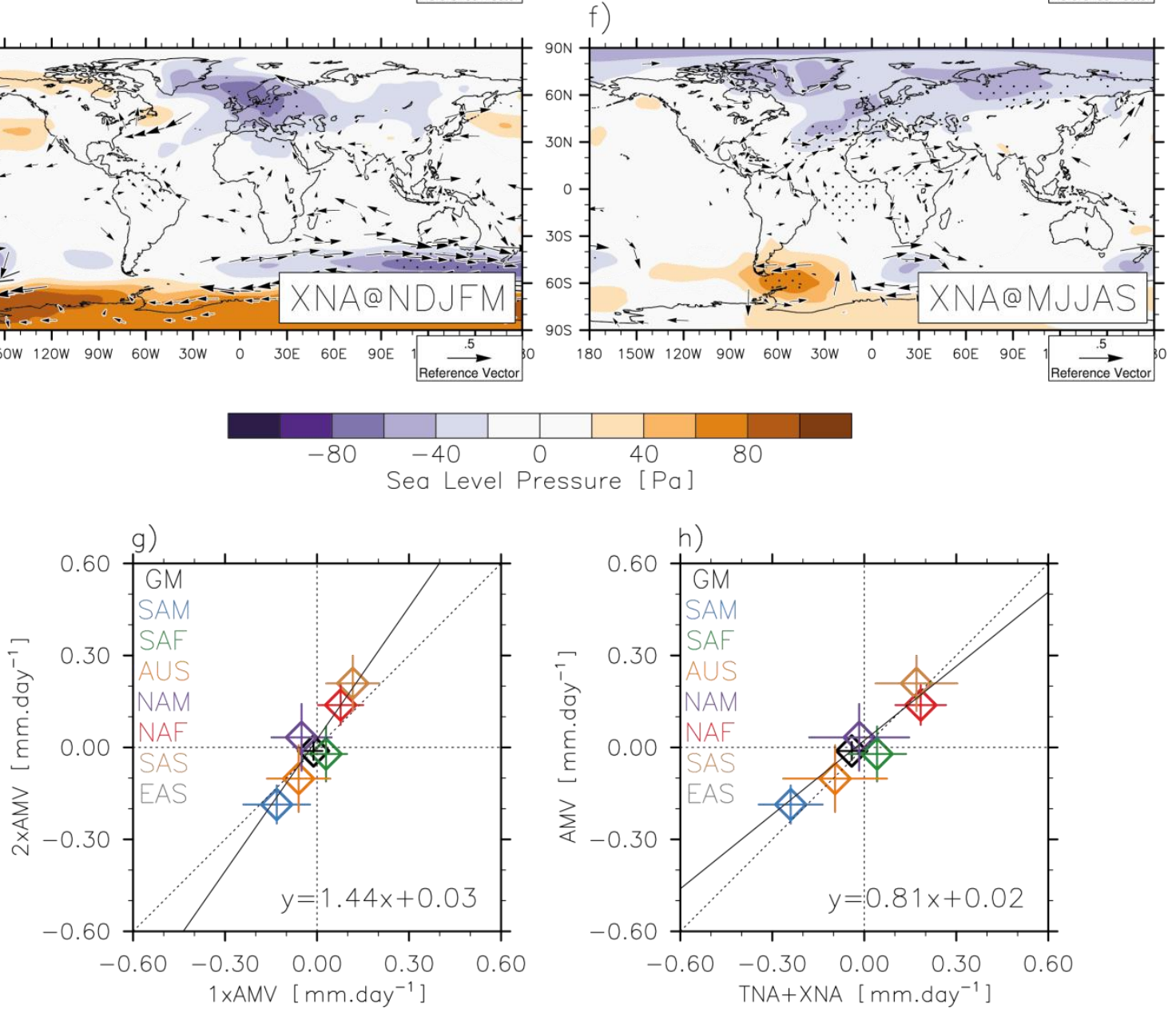
531 Figure 4: Top panels: same as in figure $1 \mathrm{~b}$ but for (a) the tropical Atlantic Ocean warming (TNA+ minus 532 TNA-) and (b) due to the extratropical Atlantic Ocean warming (XNA+ minus XNA-). Middle panels: 533 same as in figure $3 \mathrm{a}$ and figure $3 \mathrm{~b}$, but for TNA and XNA. Bottom panels: effect of 2xAMV on MI in 534 function of the effect of (left) 1xAMV on MI (right) the TNA+XNA sum on MI. Vertical and horizontal 535 black lines indicate the spread in MI, and the black line is the linear regression, as computed from the 536 sub-domain monsoons only (e.g. excluding GM). Significance in panels a-f are calculated using a 537 Student's t-test at the $95 \%$ confidence level. 